\title{
Major Floods and Tropical Cyclones over Bangladesh: Clustering from ENSO Timescales
}

\author{
Md Wahiduzzaman (D)
}

check for updates

Citation: Wahiduzzaman, M. Major Floods and Tropical Cyclones over Bangladesh: Clustering from ENSO Timescales. Atmosphere 2021, 12, 692. https://doi.org/10.3390/ atmos12060692

Academic Editors: Corrado Camera and Georgios Zittis

Received: 7 April 2021

Accepted: 26 May 2021

Published: 28 May 2021

Publisher's Note: MDPI stays neutral with regard to jurisdictional claims in published maps and institutional affiliations.

Copyright: (C) 2021 by the author. Licensee MDPI, Basel, Switzerland. This article is an open access article distributed under the terms and conditions of the Creative Commons Attribution (CC BY) license (https:// creativecommons.org/licenses/by/ $4.0 /)$.
Institute for Climate and Application Research, Nanjing University of Information Science and Technology, Nanjing 210000, China; md.wahiduzzaman@utas.edu.au

\begin{abstract}
The present study analyzed major floods and tropical cyclones (TCs) over Bangladesh on El Niño-Southern Oscillation (ENSO) timescales. The geographical location, low and almost flat topography have introduced Bangladesh as one of the most vulnerable countries of the world. Bangladesh is highly vulnerable to the extreme hazard events like floods and cyclones which are impacted by ENSO. ENSO is mainly a tropical event, but its impact is global. El Niño (La Niña) represents the warm (cold) phase of the ENSO cycle. Rainfall and cyclonic disturbances data have been used for the period of 70 years (1948-2017) and compared with the corresponding observations of the Southern Oscillation Index. Result shows that major flood events occurred during the monsoon period, and most of them are during the La Niña condition, consistent with the historical archives of flood events in Bangladesh. Synoptic conditions of these events are well matched during La Niña condition. On the other hand, the major TC cases are in the period of either pre-monsoon or post-monsoon season. The pre-monsoon cases are under neutral (developing La Niña) or El Niño and the post-monsoon cases are under La Niña, consistent with climatology studies that La Niña is favorable to have more intense TCs over the Bay of Bengal.
\end{abstract}

Keywords: flood; tropical cyclone; El Niño Southern Oscillation; Bangladesh

\section{Introduction}

Bangladesh is located at the interface of two contrasting settings with the Bay of Bengal (BoB) to the south and the Himalayas to the north. This provides the country the life-giving monsoon, on the one hand, and the catastrophic disasters like tropical cyclone (TC), storm surge, flood, drought, and erosion, on the other [1]. The geographical vulnerability of Bangladesh lies in the fact of an exceedingly flat, low-lying, alluvial plain covered by over 230 rivers and rivulets with approximately $580 \mathrm{~km}$ of exposed coastline along the BoB. As a result of its geography, Bangladesh frequently suffers from devastating floods, TCs and storm surges, tornadoes, riverbank erosion, and drought etc. [2,3] which is highly impacted by the El Niño-Southern Oscillation, a main source of year-to-year variability in weather and climate for many areas of the world [4].

The El Niño-Southern Oscillation (ENSO) is a global scale ocean/atmosphere phenomenon between the Pacific and Indo-Australian regions. In the Pacific Ocean, three basic states exist-El Niño, La Niña, or Neutral [5]. El Niño refers to the above-average sea-surface temperatures that periodically develop across the east-central equatorial Pacific. It represents the warm phase of the ENSO cycle and La Niña refers to the periodic cooling of sea-surface temperature across the east-central equatorial Pacific. It represents the cold phase of the ENSO cycle, and is sometimes referred to as a Pacific cold episode [6]. El Niño is an extensive warming of the upper ocean in the tropical eastern Pacific lasting more than 5 months. Usually the Niño3 index is defined as the mean sea surface temperature anomaly to climatology over the region $5^{\circ} \mathrm{N}-5^{\circ} \mathrm{S}, 150^{\circ} \mathrm{W}-90^{\circ} \mathrm{W}$ to identify El Niño events. Quantitative definition of an El Niño needs a Niño3 index to be larger than $0.5^{\circ}$ for 5 months at least [7]. In addition, the warmer than average waters were shown to be closely related to a global atmospheric pressure oscillation known as the Southern Oscillation. 
ENSO has an influence on flood which is defined as a relatively high flow of water that overtops the natural or artificial banks of a stream [8]. Flood causes major damage to life and property (i.e., land and buildings) in Bangladesh [9]. For example, the flood in 1987 affected 39.9\% area in Bangladesh which was devastating in nature compared to previous flood years i.e., 1955, 1963, 1969, 1970, and 1974 [10]. An increased amount of precipitation can cause flooding in Bangladesh [10]. An above normal monsoon downpour in the Ganges-Brahmaputra-Meghna drainage system is thought to be the primary cause of the 1988 flood in Bangladesh. The causes of floods are thoroughly discussed by Brammer [10]. Another natural hazard, for example, a devasting TC depends on its intensity. The BoB is a favorable breeding ground of TCs [10-21] and Bangladesh is the worst sufferer due to cyclonic casualties in the world [16]. About 5.5\% of the TCs of the global total form in the BoB [11-22] and about 1\% hit Bangladesh. On the other hand, if the TC disasters due to each of which the minimum death tolls were 5000 are considered, then it is found that a death toll of about $53 \%$ of the global total occurred in Bangladesh [1-3].

ENSO has also impact on TCs. During strong El Niño years, Bangladesh has not faced any catastrophic cyclone but experienced a high number when ENSO condition is neutral for example, during 1960-1970 period there was no strong El Niño but neutral and Bangladesh faced eighteen cyclones [23] during that time. Singh et al. [24] found a reduction rate of severe TC activity over the BoB in pre-monsoon and post-monsoon season during warm phases of ENSO. They also investigated the impact of Southern Oscillation on the cyclogenesis over the BoB during the summer monsoon and found more depressions formed in El Niño years.

Two interesting results were reported by Mandal $[25,26]$ regarding the recurving and landfall properties of the TCs of the BoB with respect to ENSO activity. In the North Indian Ocean, about $35 \%$ and $65 \%$ of the TCs are recurving and non-recurving types, respectively. TCs tracks analysis during severe El Niño years (1901 to 1990) showed 39\% and 61\% TCs have found to be recurving and non-recurving types, respectively and those TCs formed in the BoB, mostly cross the Indian coast (south of $20^{\circ} \mathrm{N}$ ) in the El Niño years whereas in La Niña years, most of the cyclones crossed coastal regions (north of $20^{\circ} \mathrm{N}$ ) of West Bengal and Bangladesh $[25,26]$. In the present study, the major floods and TCs are identified and categorized under El Niño, La Niña, and neutral ENSO. Moreover, the recurving properties of the TCs that hit Bangladesh are also categorized during ENSO time scales. This will be helpful to tackle the future climate change in Bangladesh.

TCs in BoB and their relationship with ENSO have been investigated in many earlier studies [27-29]. The influence of ENSO on TC activities in the BoB during post-monsoon season is studied by Girishkumar and Ravichandan [19] and they found more TCs formed in La Niña years than El Niño years. During La Niña years, the existence of low-level cyclonic vorticity, enhanced convection, and high TC heat potential in the BoB provided favorable conditions for TC activities [27].

This paper categorizes the major floods and TCs that affected Bangladesh on the ENSO timescales and attempts to find out the mechanisms behind it during those events by considering the synoptic conditions. The structure of this paper is organized as follows. The rainfall, TCs, and synoptic data are described in Section 2. Section 3 presents the results of the major floods and TCs activity over the Bangladesh by considering El Niño, La Niña and Neutral phase. Mechanisms are discussed also in Section 3 and conclusion is provided in Section 4.

\section{Data and Methods}

The El Niño and La Niña years are identified from the multivariate ENSO Index (Table 1). The Southern Oscillation Index (SOI) is calculated from the monthly fluctuations in the air pressure difference between Tahiti and Darwin. This SOI uses the surface pressure normalized by a standard deviation. Sustained negative values of the SOI indicate El Niño episodes and positive values of the SOI are associated with La Niña episode [6,30]. These data (1948-2017) were collected from Bureau of Meteorology, Australia. The same period 
of quality controlled rainfall data in Bangladesh were collected from both Bangladesh Meteorological Department and Bangladesh Water Development Board, respectively. The data are then compared against the corresponding SOI data on a monthly basis. To find out the major inland floods of Bangladesh, 35\% affected area are considered and therefore, 7 floods are identified. The events of the floods are collated in tabular form as function of time by considering El Niño and La Niña. Neutral considers the SOI value which is in between +0.5 and -0.5 .

Table 1. Identified years under the phase of ENSO.

\begin{tabular}{|c|c|}
\hline Phase of ENSO & Years \\
\hline El Niño & $\begin{array}{c}1958,1966,1973,1978,1980,1983,1987,1988,1992,1995,19982003, \\
\text { 2007, 2010, } 2014\end{array}$ \\
\hline La Niña & $\begin{array}{c}1950,1951,1955,1956,1962,1971,1974,1976,1989,1999,20002008, \\
\text { 2011, } 2012\end{array}$ \\
\hline Neutral & $\begin{array}{c}\text { 1948-1949, 1952-1954, 1957, 1959-1961, 1963-1965, 1967-1970, 1972, } \\
\text { 1975, 1977, 1979, 1981-1982, 1984-1986, 1990-1991, 1993-1994, } \\
\text { 1996-1997, 2001-2002, 2004-2006, 2009, 2013-2014, 2015-2016. }\end{array}$ \\
\hline
\end{tabular}

BoB TCs data have been collected from Bangladesh Meteorological Department and India Meteorological Department. The data are again compared against the corresponding SOI data on monthly basis. Again, to find out the major tropical cyclones of Bangladesh, maximum sustained wind speeds is considered and therefore, 12 tropical cyclones are identified. The TC event is collated in tabular form as a function of time under El Niño and La Niña. Surface precipitable water, surface pressure, sea level pressure, precipitation and surface runoff anomalies are calculated from NOAA Physical Science Laboratory using NCEP/NCAR reanalysis data. The NCEP/NCAR reanalysis does not accurately depict the pressure and rainfall from tropical cyclones, but it is considered to be more representative of the large-scale composite synoptic environment. Monthly ENSO SST series are downloaded from NOAA physical sciences laboratory. The vertical wind shear ( $u$ and $v$ as zonal and meridional velocity components respectively) is calculated according to the formula below

$$
\sqrt{\left(u_{200}-u_{850}\right)^{2}+\left(v_{200}-v_{850}\right)^{2}}
$$

The low-level vorticity and relative humidity here are represented by $850-\mathrm{hPa}$ pressure level vorticity and relative humidity. Wind, vorticity, and humidity data are downloaded from NOAA physical sciences laboratory.

\section{Results}

\subsection{Categorizing of Major Floods on ENSO Timescales}

The monthly and seasonal percentage of the total annual rainfall from 1948 to 2017 have been shown in Figure 1. The highest percentage of the total annual rainfall $(21.1 \%)$ is observed in the month of July (Figure 1a). Besides, the percentage of the total annual rainfall is relatively high in June (19.93\%), August (17.14\%), and September (13.05\%). On the other hand, the percentage of the total annual rainfall $(0.08 \%)$ is lowest in February (Figure 1a). There are mainly four seasons in Bangladesh-winter (December-February), pre-monsoon (March-May), monsoon (June-August) and post-monsoon (October-November). Seasonally, the highest percentage of the total annual rainfall (70.6\%) is observed in monsoon and lowest $(1.4 \%$ ) in winter (Figure 1b). Pre-monsoon and post-monsoon contribute $20 \%$ and $8 \%$ of total respectively (Figure $1 \mathrm{~b}$ ). 


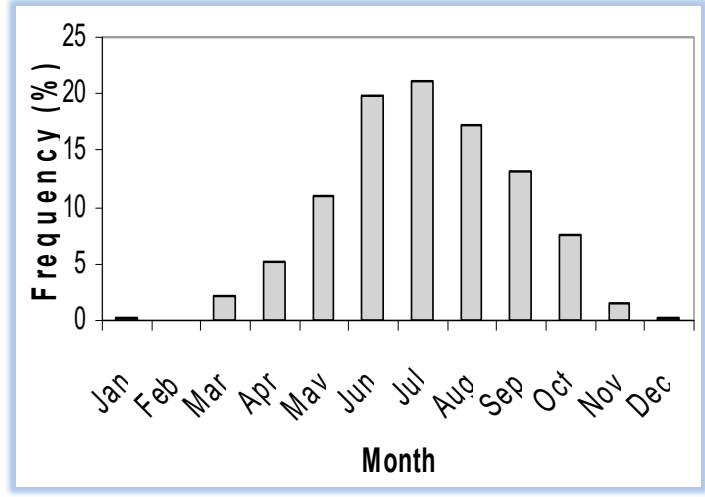

(a)

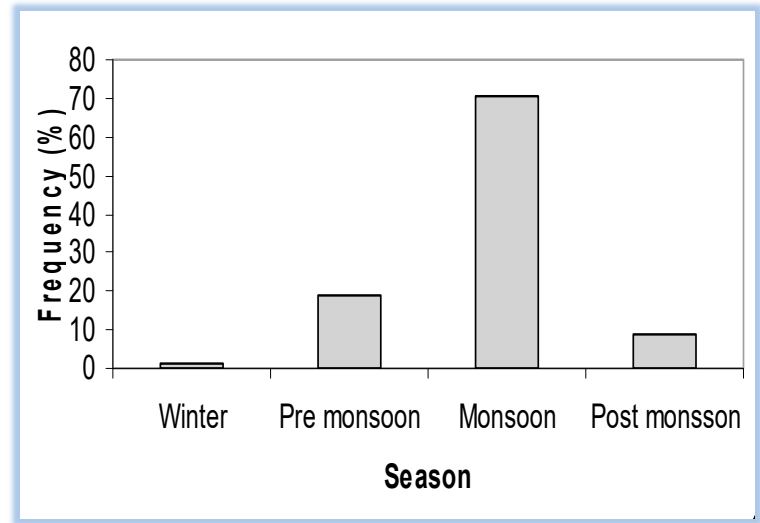

(b)

Figure 1. Monthly (a) and seasonal (b) percentage of the total annual rainfall during 1948-2017.

As shown in Figure 1b, Bangladesh receives most of the rainfall during monsoon season when the floods generally occur depending on the rainfall intensity in the catchments of the rivers. The major flood years have been categorized based on the amount of large affected area (at least one third portion of Bangladesh). At least two-third of the total area in Bangladesh was affected by the flood of 1988 and 1998 whereas, at least one-third part of Bangladesh was affected by the flood of 1955, 1974, 1987, 2004, and 2007 (Table 2). These years are then considered under the phase of ENSO to find which years belong to which ENSO phase (Table 2) so that a conclusion can be made on major floods of Bangladesh (Figure 2a-g) under ENSO timescales. The flood years of 1955 (Figure 2a), 1974 (Figure 2b), 1988 (Figure 2d), 1998 (Figure 2e) belong to La Niña and 1987 (Figure 2c), 2004 (Figure 2f) in El Niño and 2007 (Figure 2g) belongs to neutral ENSO phase.

Table 2. Categorizing the major floods in Bangladesh on ENSO timescales.

\begin{tabular}{ccccc}
\hline Year & Flood Affected Area $(\mathbf{S q} \mathbf{~ k m})$ & Affected Area $\mathbf{( \% )}$ & SOI & Phase of ENSO \\
\hline 1955 & 50,700 & 34.2 & 2.4 & La Niña \\
1974 & 52,720 & 36.6 & 1.4 & La Niña \\
1987 & 57,491 & 39.9 & -2.2 & El Niño \\
1988 & 89,970 & 63 & 2.8 & La Niña \\
1998 & 100,250 & 68 & 1.9 & La Niña \\
2004 & 55,000 & 38 & -1.2 & El Niño \\
2007 & 62,289 & 42.2 & 0.1 & Neutral \\
\hline
\end{tabular}

A flood occurred during July-August in 1955 which inundated 34.20\% area of Bangladesh and SOI indicates positive value in this time, as a result La Niña was prominent in that period (Figure 2a). La Niña (Figure 2a,b,d,e) was also prominent in 1974 (inundated about 36.6\%), 1988 (inundated about 60\%), 1998 (maximum inundated $\sim 68 \%$ area of Bangladesh) and floods occurred in monsoon period (July-August). On the other hand, El Niño (Figure 2c,f) was also prominent in 1987 (inundated about 40\%) and 2004 (inundated about 38\%), respectively. A flood in 2007 (inundated about 42\%) was recorded under neutral phase of ENSO (Figure $2 \mathrm{~g}$ ). 


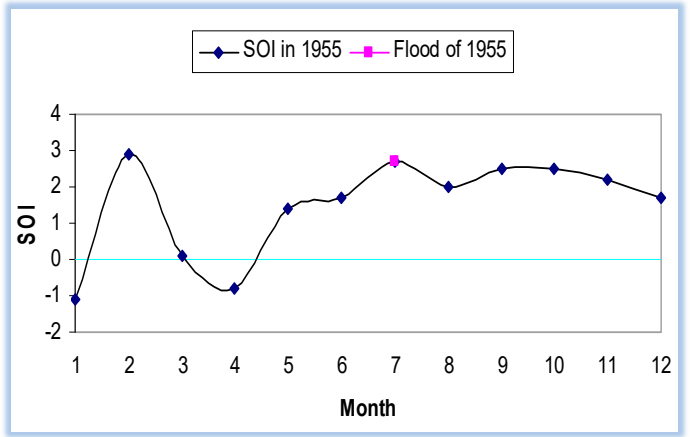

(a)

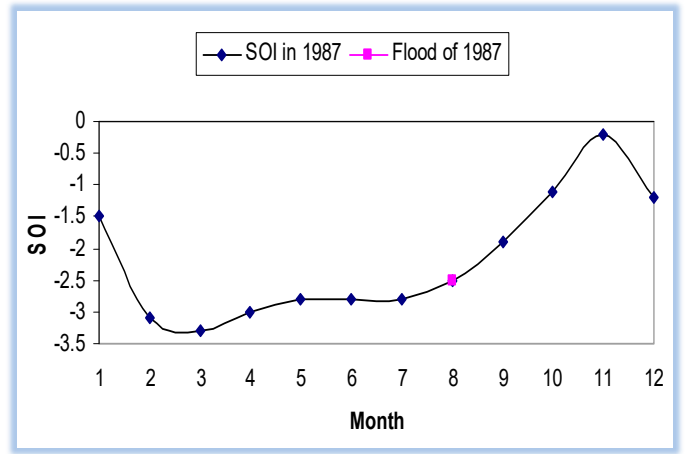

(c)

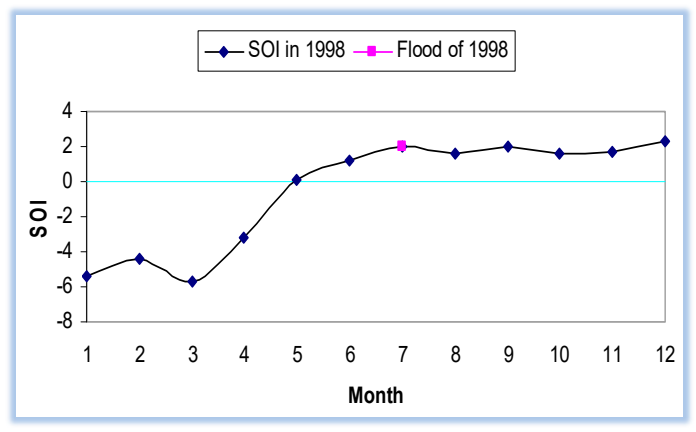

(e)

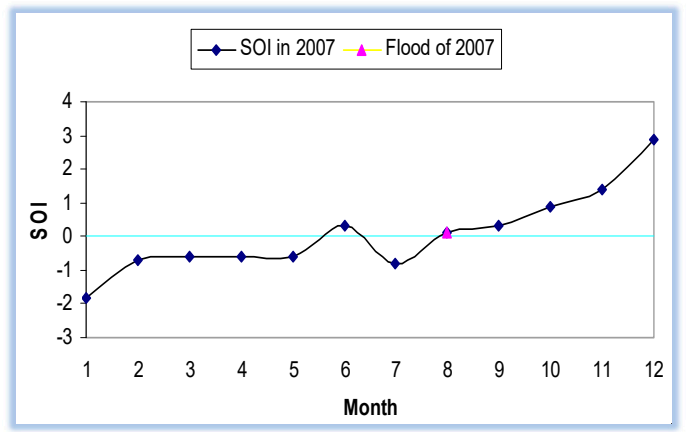

(g)

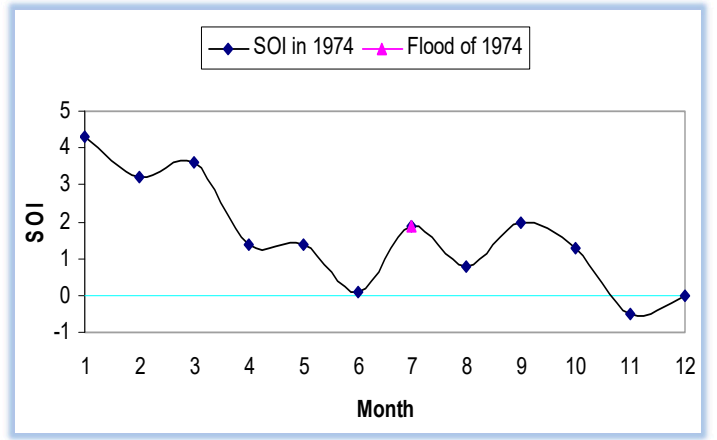

(b)

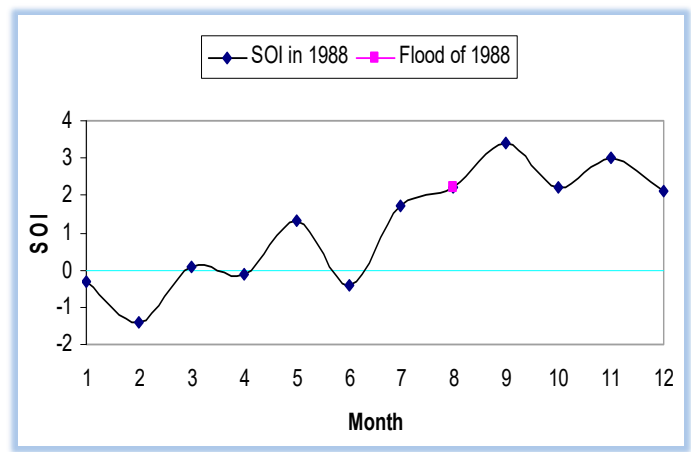

(d)

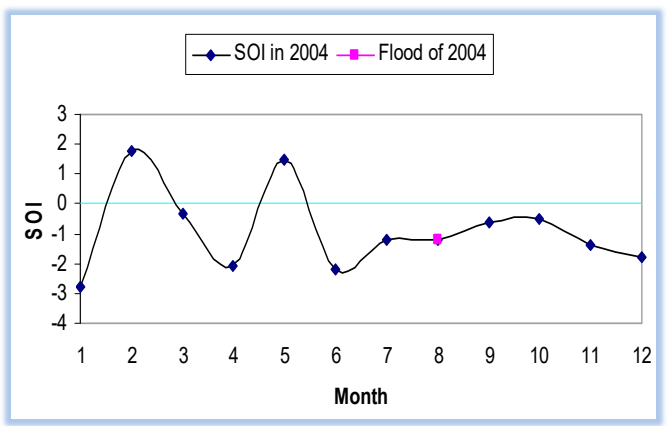

(f)

Figure 2. Seven major floods (a) 1955, (b) 1974, (c) 1987, (d) 1988, (e) 1998, (f) 2004, (g) 2007 over Bangladesh during ENSO phase. Black line represents the variability of SOI, and green line is the base line where positive value $(>0.5)$ of SOI indicates El Niño, negative value $(<-0.5)$ indicates La Niña, and rest $(-0.5$ to 0.5$)$ shows the neutral ENSO. Magenta dot indicates the month of the year when flood started. 


\subsection{Categorizing of Major TCs on ENSO Timescales}

Twelve severe cyclonic storms with hurricane speed (on the basis of maximum wind speeds) were identified (Table 3). La Niña (Figure 3a,e,h,l) was prominent in 1960 (wind speed $193 \mathrm{~km} / \mathrm{h}$ ), 1970 (wind speed $193 \mathrm{~km} / \mathrm{h}$ ), 1988 (wind speed $193 \mathrm{~km} / \mathrm{h}$ ), and 2007 (wind speed $193 \mathrm{~km} / \mathrm{h}$ ). On the other hand, El Niño (Figure 3i,j,k) was also prominent in 1991 (wind speed $225 \mathrm{~km} / \mathrm{h}$ ), 1994 (wind speed $200 \mathrm{~km} / \mathrm{h}$ ), and 1997 (wind speed $230 \mathrm{~km} / \mathrm{h}$ ), respectively. Rest five TCs 1961 (wind speed $161 \mathrm{~km} / \mathrm{h}$ ), 1963 (wind speed $202 \mathrm{~km} / \mathrm{h}$ ), 1965 (wind speed $184 \mathrm{~km} / \mathrm{h}$ ), 1974 (wind speed $161 \mathrm{~km} / \mathrm{h}$ ), 1985 (wind speed $154 \mathrm{~km} / \mathrm{h}$ ) were under neutral phase of ENSO (Figure 3b-d,f,g).

Table 3. Categorizing of major TCs in Bangladesh.

\begin{tabular}{ccccc}
\hline Year & Month & Crossing Area & SOI & Phase of ENSO \\
\hline 1960 & 30-31 October & North Part of Chittagong & 0.8 & La Niña \\
1961 & 5-9 May & Meghna Estuary & 0.2 & Neutral \\
1963 & 28 May & North Part of Chittagong & 0.2 & Neutral \\
1965 & 7-15 December & Cox's Bazar & 0 & Neutral \\
1970 & 13 November & North Part of Chittagong & 2.8 & La Niña \\
1974 & 24-28 November & Chittagong & -0.5 & Neutral \\
1985 & 22-25 May & Chittagong & 0.3 & Neutral \\
1988 & 24-30 November & Khulna & 3 & La Niña \\
1991 & 25-30 April & North Part of Chittagong & -2 & El Niño \\
1994 & 24 April-2 May & Teknaf & -1.7 & El Niño \\
1997 & 15-19 May & Teknaf & -3 & El Niño \\
2007 & 11-15 November & Khulna Barisal & 1.4 & La Niña \\
\hline
\end{tabular}

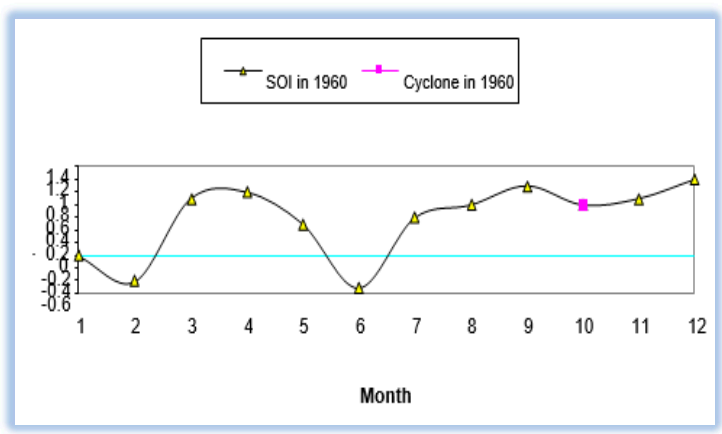

(a)

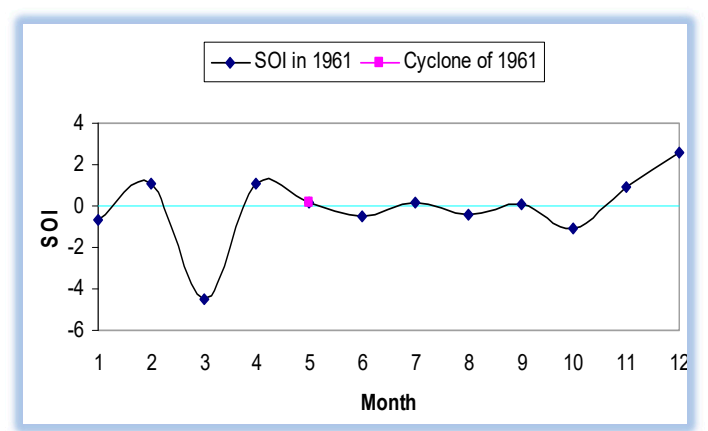

(b)

Figure 3. Cont. 


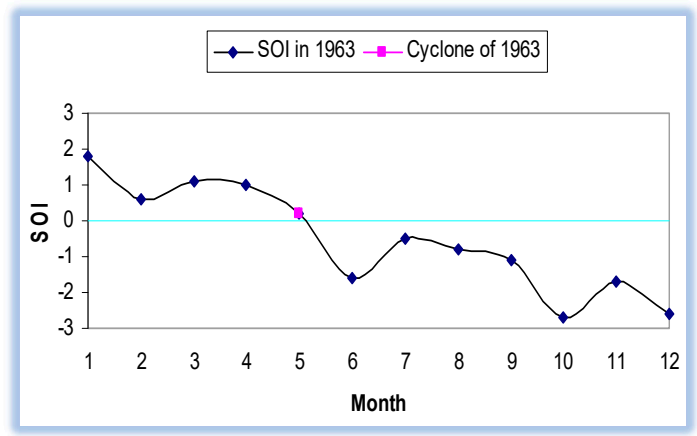

(c)

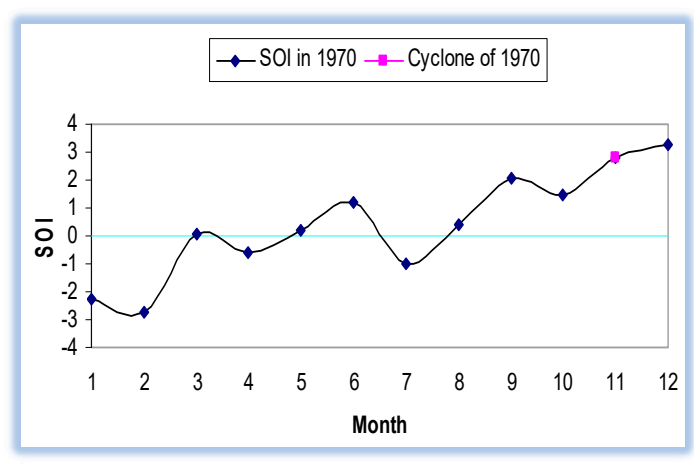

(e)

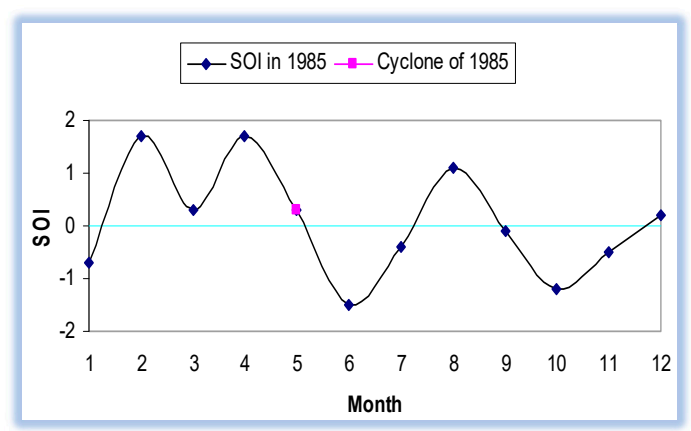

(g)

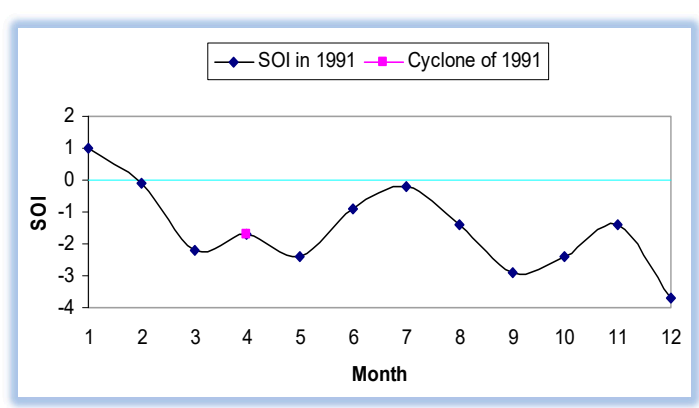

(i)

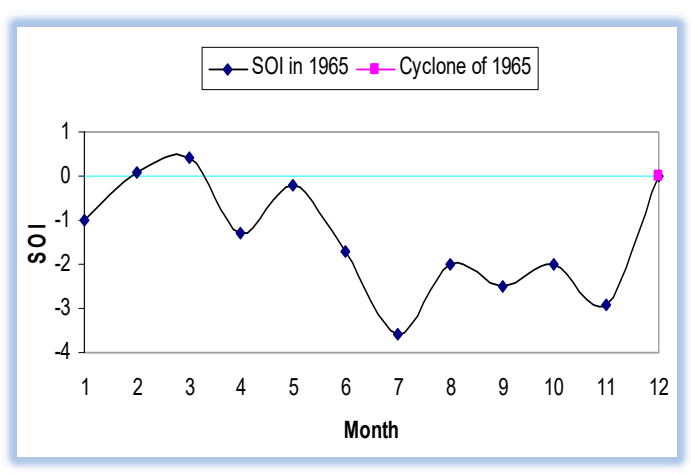

(d)

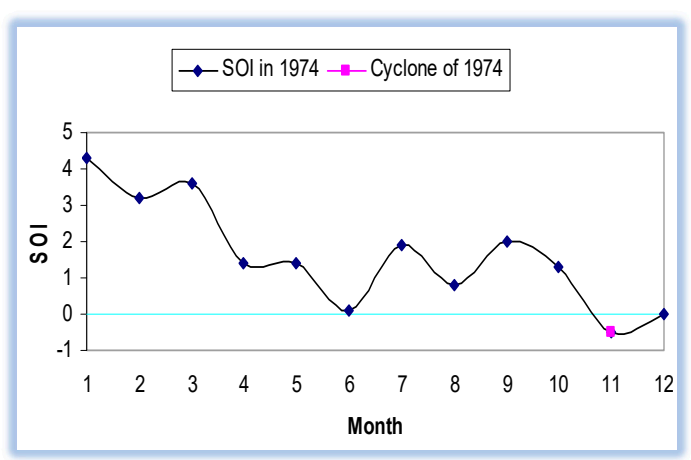

(f)

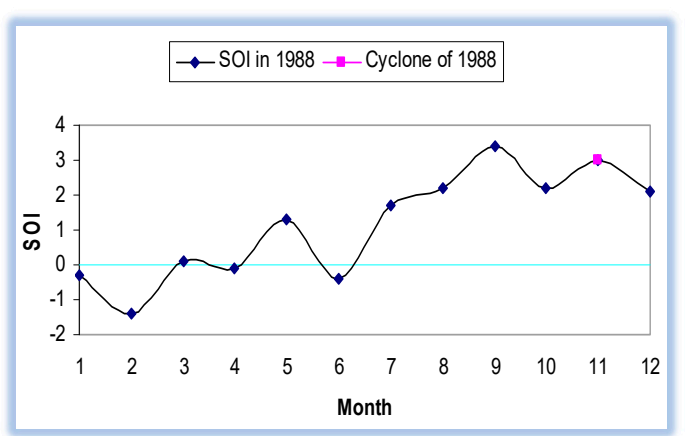

(h)

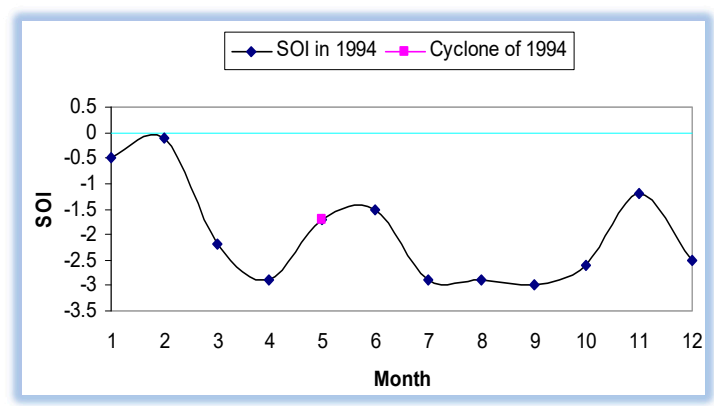

(j)

Figure 3. Cont. 


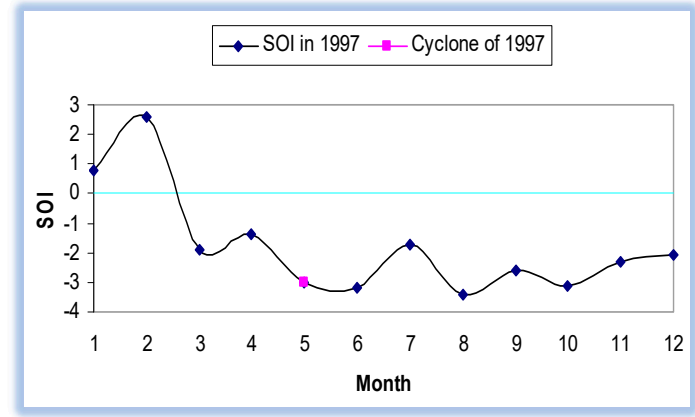

(k)

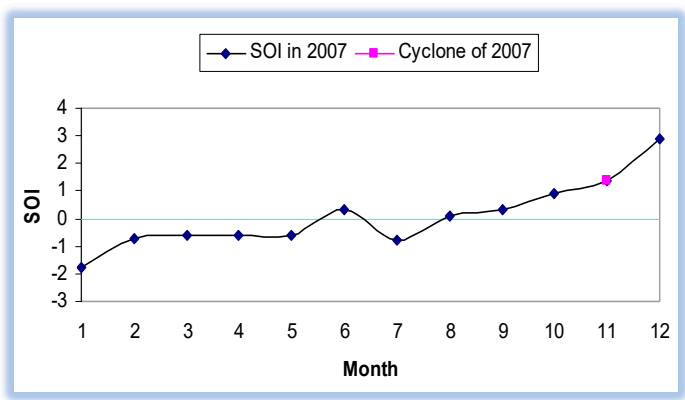

(1)

Figure 3. Twelve major cyclones (a) 1960, (b) 1961, (c) 1963, (d) 1965, (e) 1970, (f) 1974, (g) 1985, (h) 1988, (i) 1991, (j) 1994, (k) 1997, (l) 2007 over Bangladesh under ENSO phase. Black line represents the variability of SOI, and green line is the base line where positive value $(>0.5)$ of SOI indicates El Niño, negative value $(<-0.5)$ indicates La Niña, and rest $(-0.5$ to 0.5$)$ shows the neutral ENSO phase. Magenta dot indicates the month of the year when cyclone started.

As a case study among ten cyclones, the re-curvature of cyclone tracks has been studied (Figure 4a-j). Ten TCs tracks analysis over the BoB (affected Bangladesh) show that the re-curvature takes place between $14-19^{\circ} \mathrm{N}$ for those developed in El Niño and $12-16^{\circ} \mathrm{N}$ for those developed in La Niña with one exception of 29 October, 1999 cyclone which had no re-curvature (Table 4 and Figure $4 a-j)$.

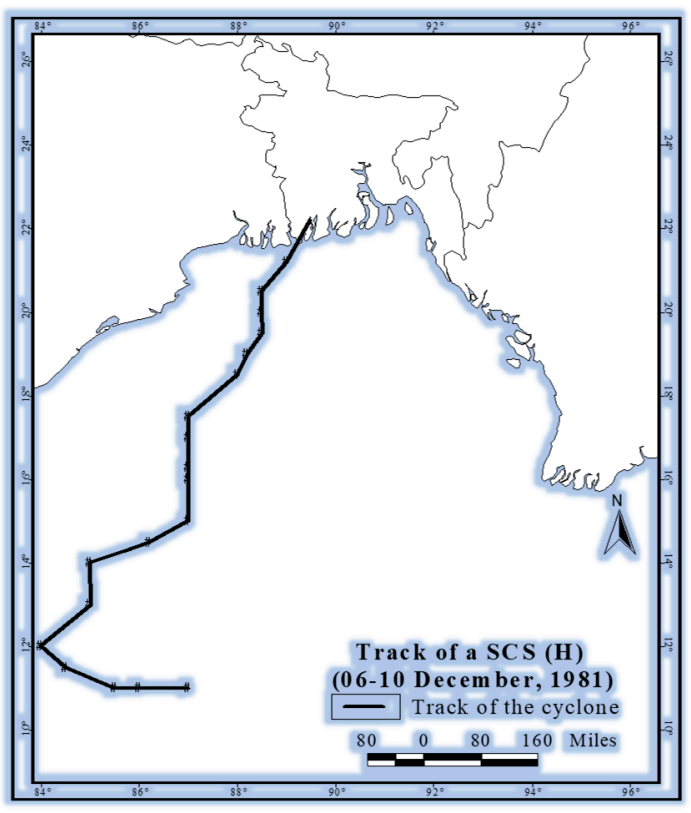

(a)

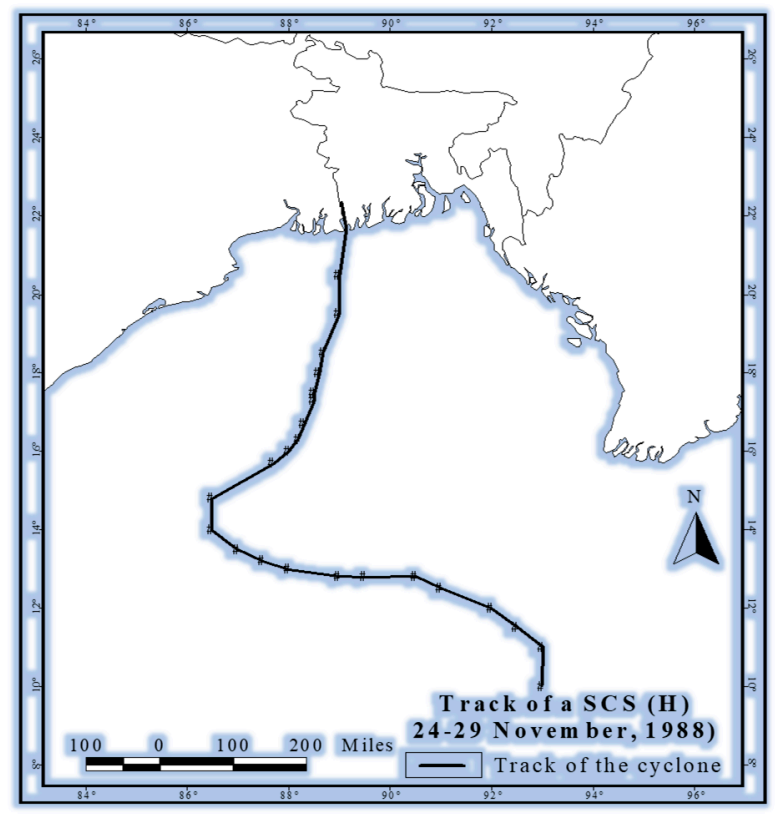

(b)

Figure 4. Cont. 


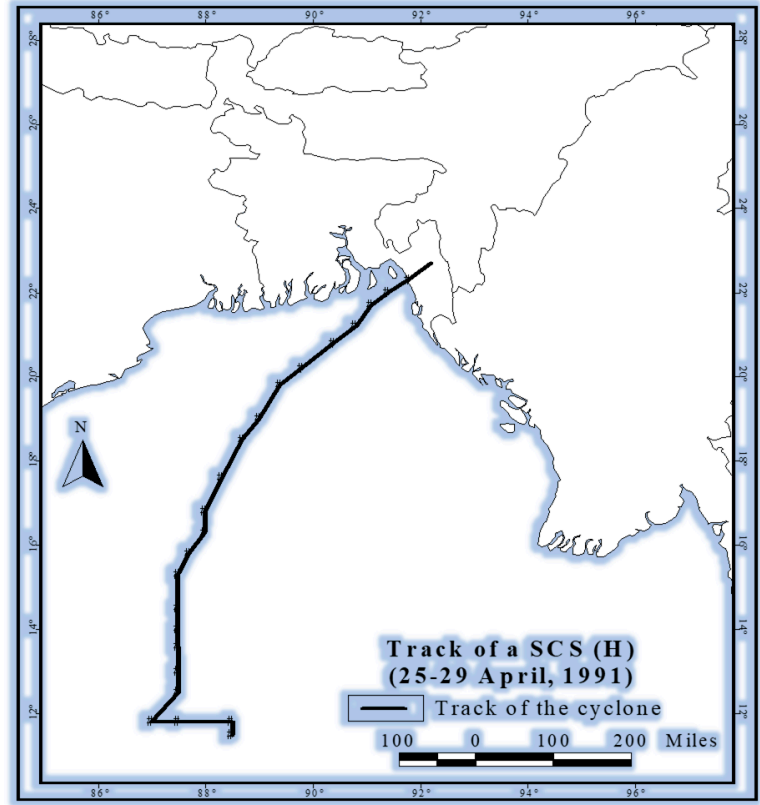

(c)

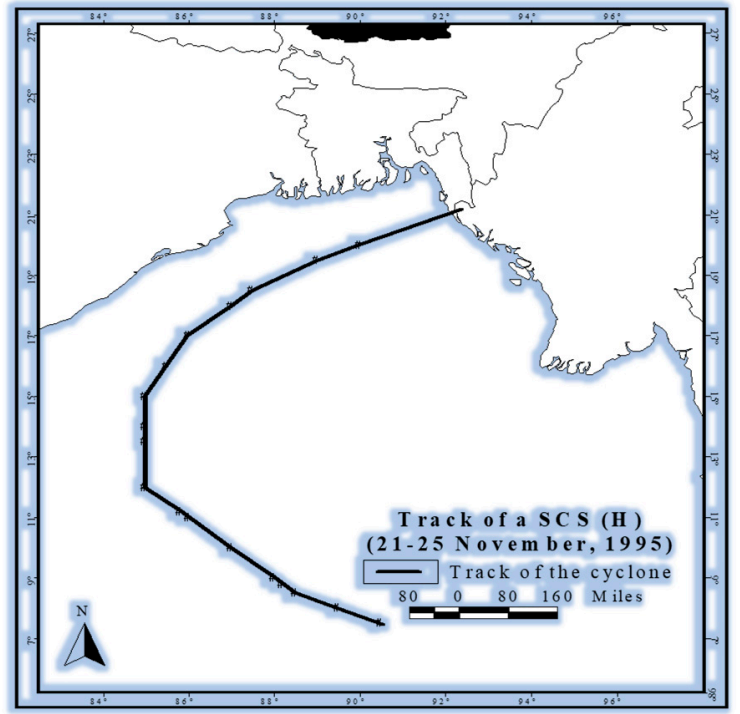

(e)

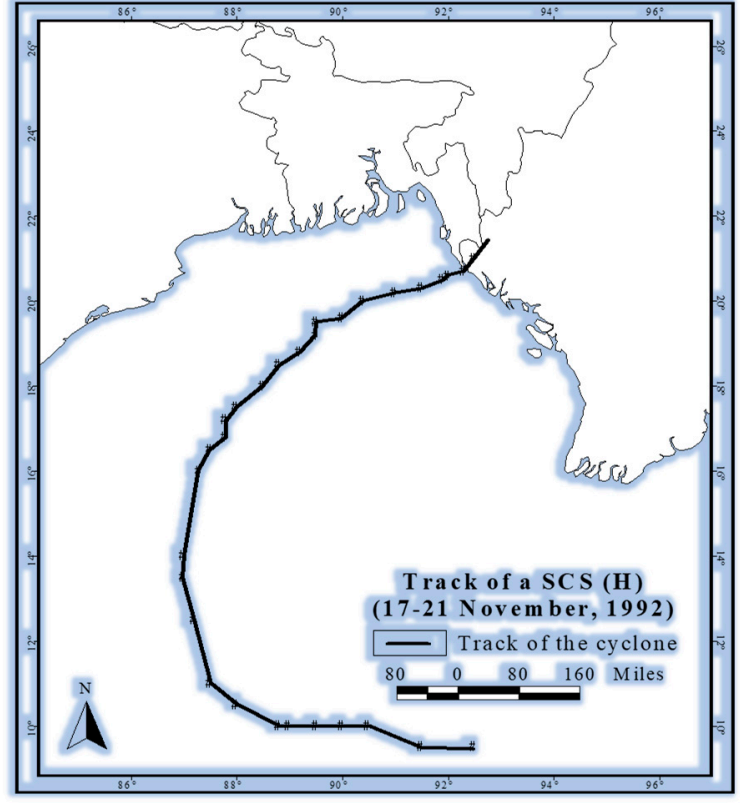

(d)

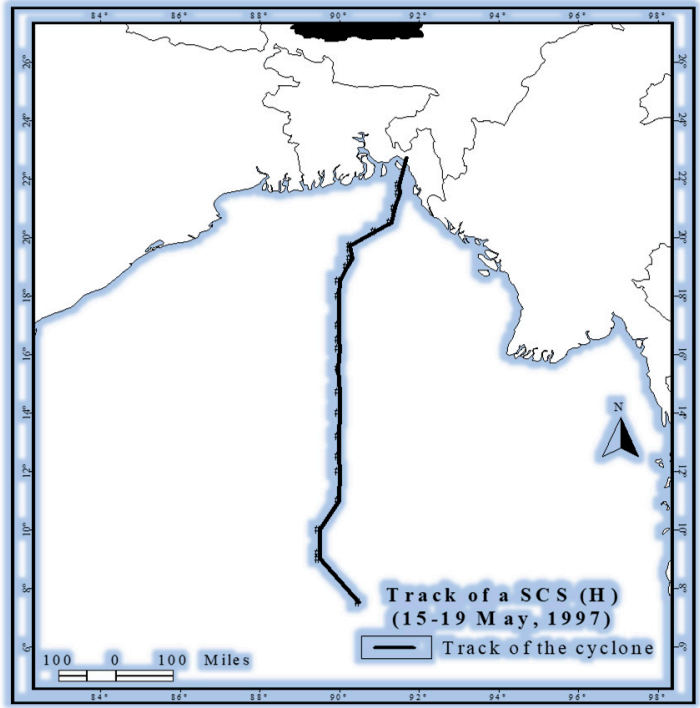

(f)

Figure 4. Cont. 


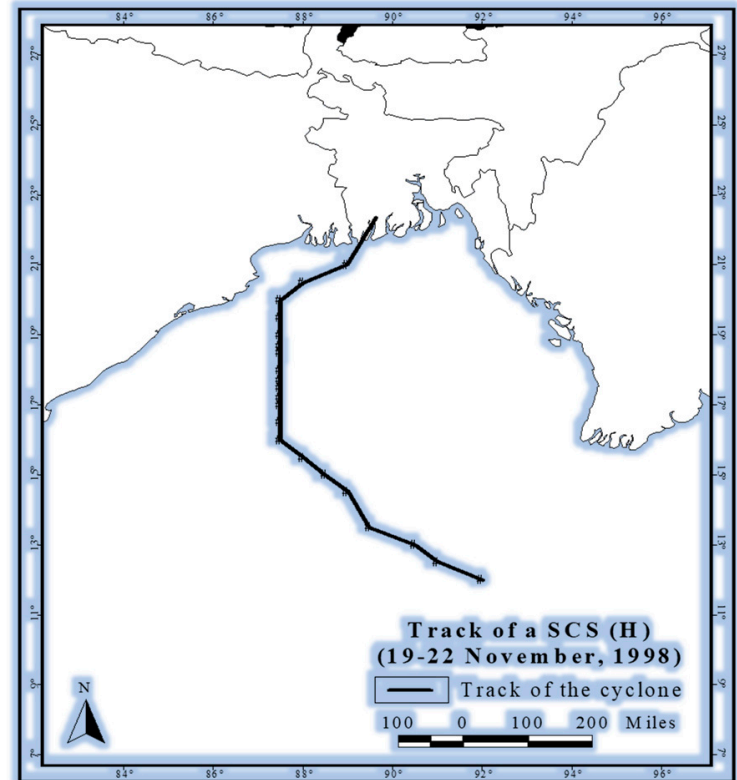

(g)

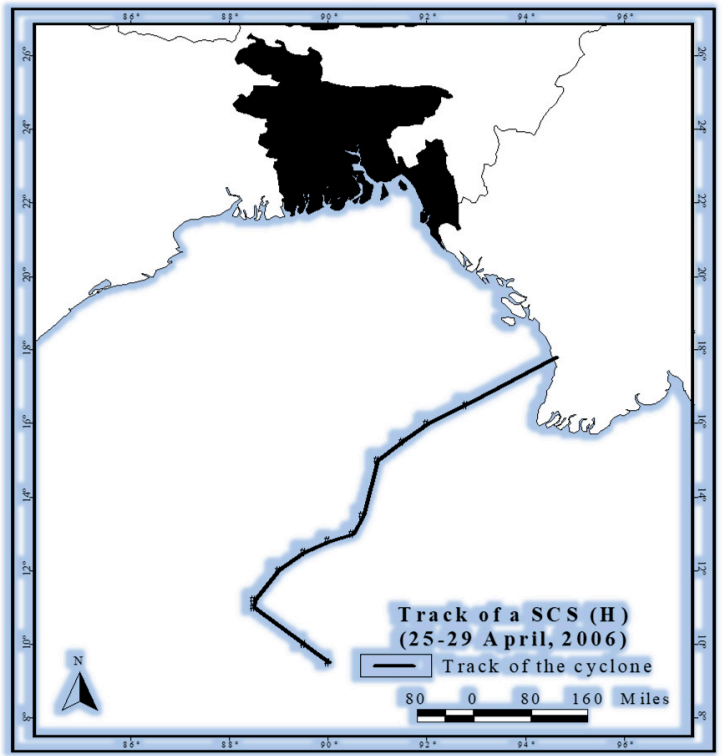

(i)

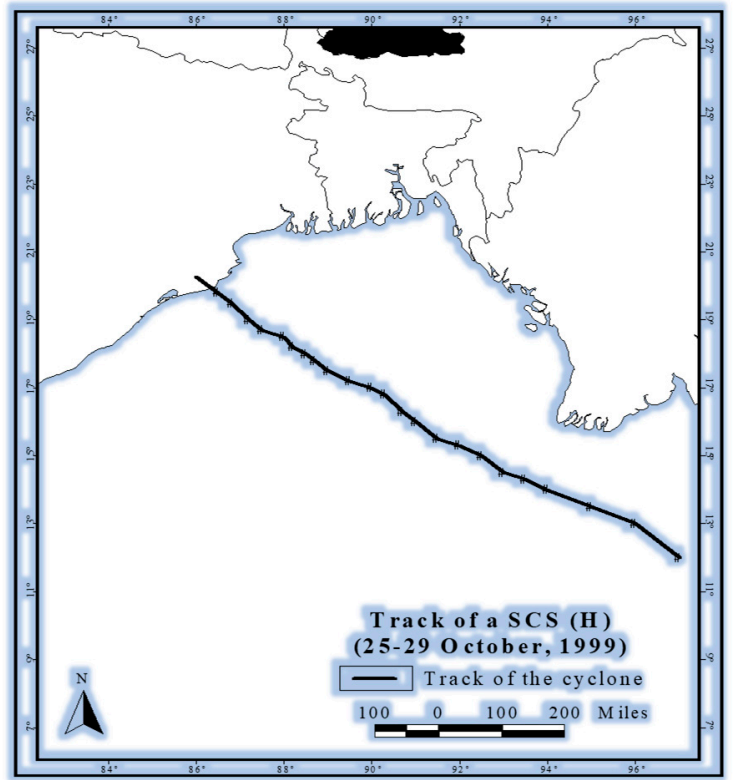

(h)

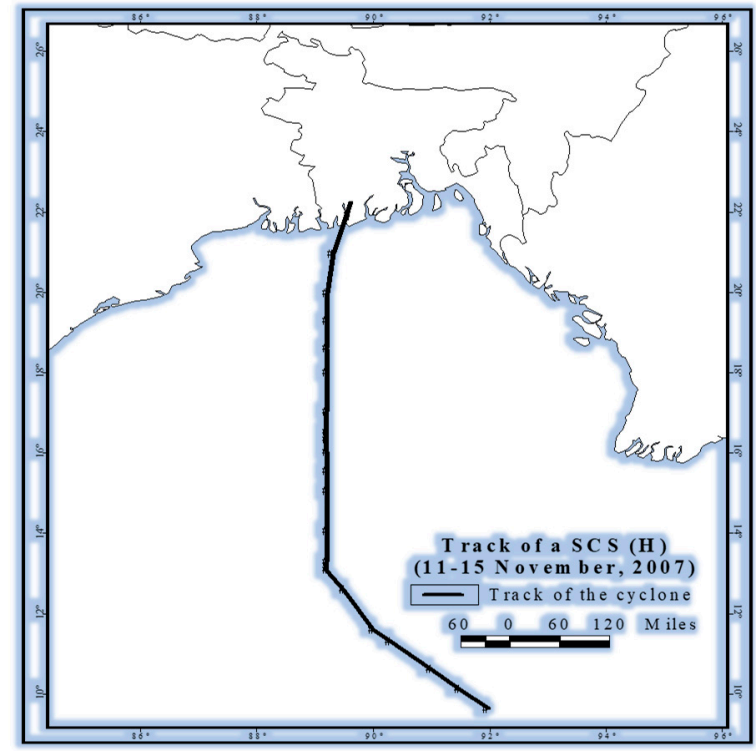

(j)

Figure 4. Ten major TC tracks in (a) 1981, (b) 1988, (c) 1991, (d) 1992, (e) 1995, (f) 1997, (g) 1998, (h) 1999, (i) 2006, and (j) 2007 over Bangladesh during ENSO. Black line and dot represent the track and movement over time.

Table 4. Re-curvature analysis of the major ten cyclones over Bangladesh during ENSO.

\begin{tabular}{|c|c|c|c|c|c|c|}
\hline Cyclone & Month & SOI & ENSO Phase & $\begin{array}{c}\text { Point of } \\
\text { Formation }(\mathrm{N})\end{array}$ & $\begin{array}{l}\text { Lat. of Re-Curvature } \\
\text { (N) }\end{array}$ & $\begin{array}{c}\text { Point of } \\
\text { Landfall (N) }\end{array}$ \\
\hline 1981 & December & 0.7 & La Niña & $11^{\circ}$ & $12^{\circ}-16^{\circ}$ & $21.2^{\circ}$ \\
\hline 1988 & November & 3 & La Niña & $10^{\circ}$ & $14^{\circ}$ & $20.5^{\circ}$ \\
\hline 1991 & April & -2 & El Niño & $11.5^{\circ}$ & $16^{\circ}$ & $22.3^{\circ}$ \\
\hline 1992 & November & -1.4 & El Niño & $9.5^{\circ}$ & $16^{\circ}$ & $21^{\circ}$ \\
\hline 1995 & November & -0.1 & El Niño & $7.5^{\circ}$ & $14^{\circ}$ & $20^{\circ}$ \\
\hline 1997 & May & -3 & El Niño & $7.5^{\circ}$ & $19^{\circ}$ & $21.8^{\circ}$ \\
\hline 1998 & November & 1.7 & La Niña & $12^{\circ}$ & $16^{\circ}$ & $21^{\circ}$ \\
\hline 1999 & October & 1.5 & La Niña & $12^{\circ}$ & Straight & $19.8^{\circ}$ \\
\hline 2006 & April & 1.5 & La Niña & $9.5^{\circ}$ & $12^{\circ}$ & $16.5^{\circ}$ \\
\hline 2007 & November & 1.4 & La Niña & $9.5^{\circ}$ & $12^{\circ}$ & $21^{\circ}$ \\
\hline
\end{tabular}




\subsection{Mechanisms}

The ENSO affects Indian monsoon through an interaction between the equatorial Walker circulation and the regional Hadley circulation, which are considered as the world's two prominent and important atmospheric zonal and meridional circulations, respectively. There is a reduction of rainfall in Bangladesh for all seasons during El Niño events and Bangladesh did not face any catastrophic flood during the strong El Niño events. However, the weak El Niño and the transitional time from El Niño to La Niña are favourable for having floods and TCs in Bangladesh. There is a strong correlation between monsoon years and strong La Niña events. During El Niño years, Bangladesh is not struck by any catastrophic cyclone but when the ENSO index is small (either negative or positive) and when $28.5^{\circ} \mathrm{C}$ isotherm stays left of $165^{\circ} \mathrm{E}$ longitude then Bangladesh is likely being hit by a cyclone. This is the case for seeing cyclones in the pre-monsoon season in El Niño events. When the ENSO index is positive, Walker circulation is strong, atmospheric pressure in pacific is high and wind is easterly. During the negative ENSO index phase, the Walker circulation is weakened, and the easterly wind is reversed. When the Walker circulation is weakened then Hadley circulation gets stronger. The strength of Bangladesh monsoon is governed by the movements of cyclonic disturbances formed in the Pacific. During the weak or moderate El Niño events, the Hadley circulation may not be very strong and allows some of the tropical disturbances to cross into the BoB and enter up to Bangladesh region causing flood and cyclone, as Bangladesh falls between 22 and $26^{\circ} \mathrm{N}$ of the equator [22].

As shown in Sections 3.1 and 3.2, Bangladesh faces more floods and TCs during La Niña. Figure 5 shows the composite anomalies of precipitable water, surface pressure, sea level pressure, surface runoff, and precipitation during La Niña events. We can see that these synoptic conditions are favourable in La Niña. For example, the surface precipitable water is positively correlated in the northern area of Bangladesh (Figure 5a) where the major river systems in Bangladesh are located and Himalaya is also located in the north of Bangladesh. Other synoptic variables (surface pressure, sea level pressure, surface runoff, and precipitation climatology) are favorable for flood events in La Niña (Figure 5b-e). Figure 6 shows the annual average anomalies of relative humidity, sea surface temperature, vorticities, and vertical wind shear in La Niña phase. During La Niña period, the low vertical wind shear and enhanced low level vorticity, relative humidity, sea surface temperature are more favorable environment for TC development in the BoB. This is consistent with the study by Wahiduzzaman et al. [29]. 


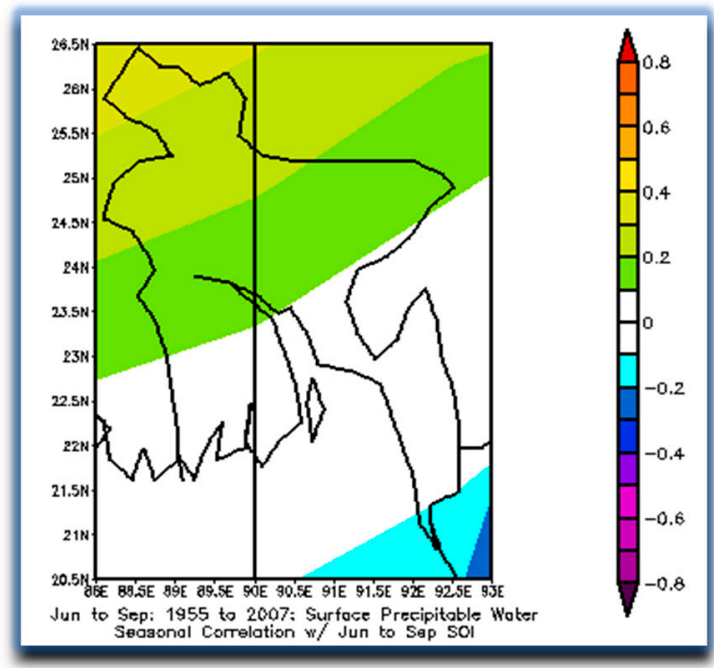

(a)

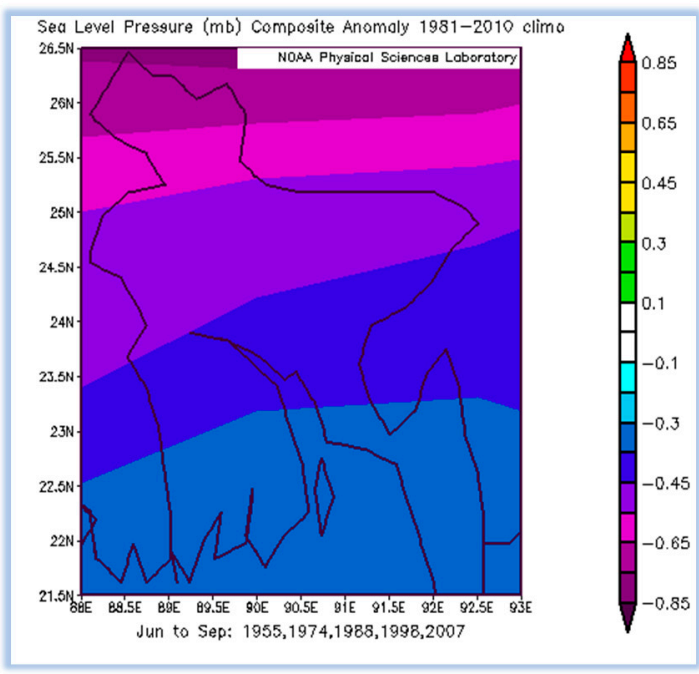

(c)

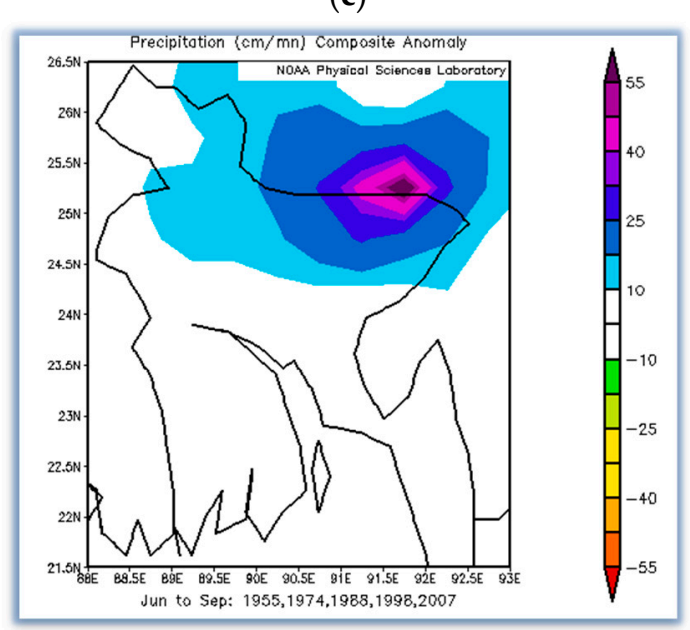

(e)

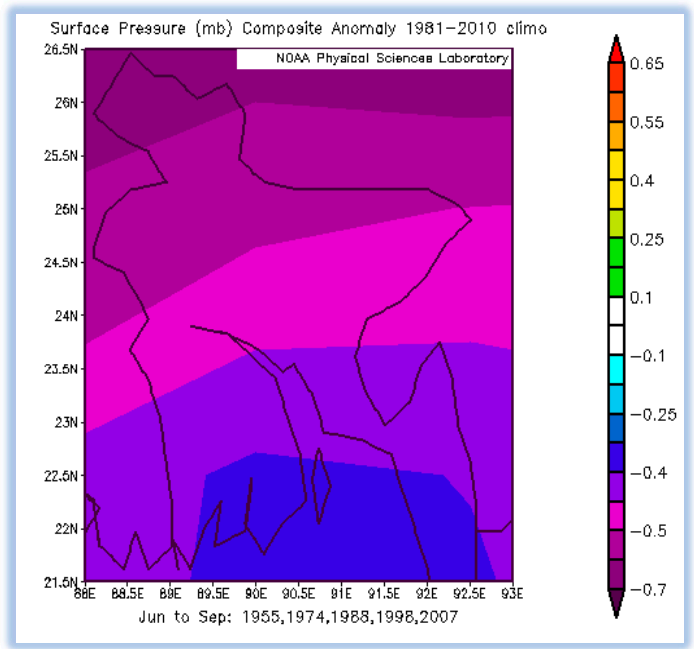

(b)

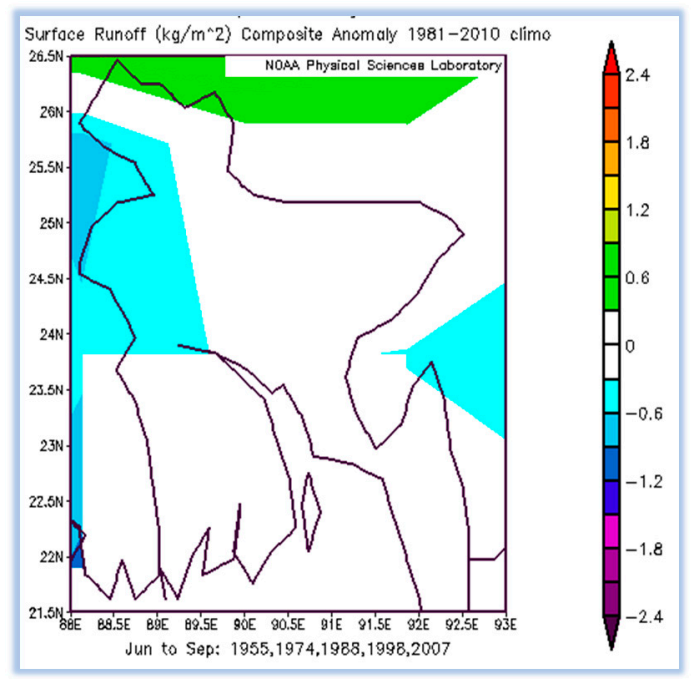

(d)

Figure 5. Synoptic conditions (a) surface precipitable water, (b) surface pressure, (c) sea level pressure, (d) surface runoff, and (e) precipitation anomaly) during La Niña. 

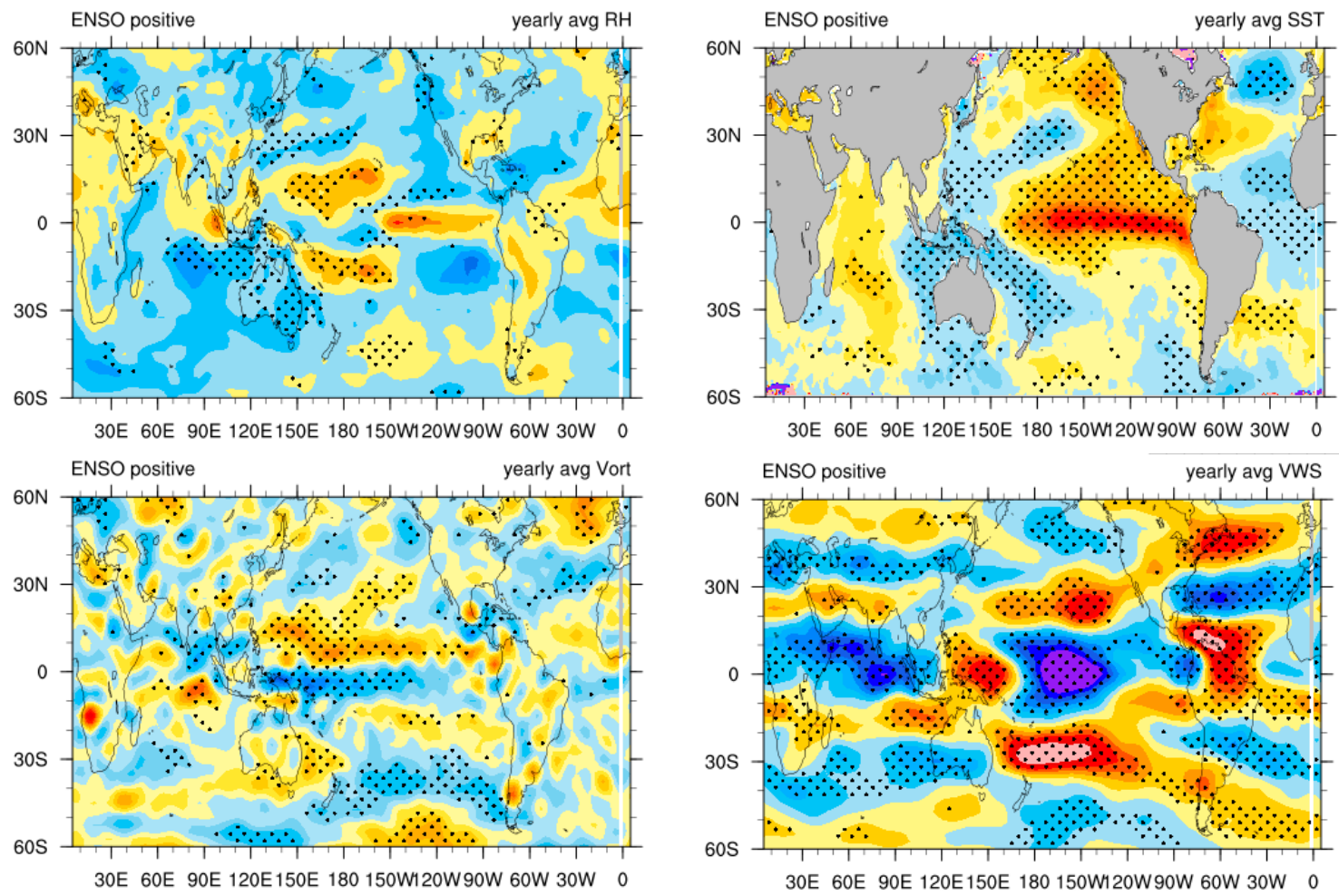

Figure 6. Relative humidity, sea surface temperature, vorticities, and vertical wind shear anomalies during ENSO positive/La Niña phase. Blue (Yellow, Red, and Pink) shade represents negative (positive) units. Dot points indicate $>5 \%$ significance level.

\section{Conclusions}

The geographical location, land characteristics, multiplicity of rivers, and the monsoon climate render Bangladesh highly vulnerable to natural hazards like TC, storm surge, flood, drought, tornado, riverbank erosion etc. Flood and TC are not a new phenomenon in Bangladesh. A total of 7 floods and 14 TCs were more devasting and catastrophic in terms of their intensity and percentage of total affected area.

In an El Niño event, excess rainfall is seen in July and deficit is observed in AugustSeptember and during the La Niña event, the excess rainfall is observed in July-September (Figure 7). Floods occurred during July-September and the flooding years of 1955, 1974, 1988, 1998, and 2007 were found under La Niña and 1987, 2004 were in El Niño. About 5 floods were interlinked with excess rainfall and La Niña event whereas 2 floods were under the deficit rainfall and El Niño event. So, the excess and deficit of rainfall are not always responsible for a flood occurrence in Bangladesh.

Four cyclones belong to La Niña condition which hit northern and north-western part of Chittagong and three cyclones belong to El Niño condition which hit southern part of Chittagong with exception of 1991 and the rest five cyclones belong to neutral ENSO. Among these five cyclones, four cyclones are found under weak La Niña and if the neutral condition is not considered then Bangladesh faces more TCs during La Niña. The re-curvature takes place in higher latitudes for those developed in El Niño than La Niña phase. Synoptic variables support the occurrence of major floods and TCs in Bangladesh under La Niña phase. 


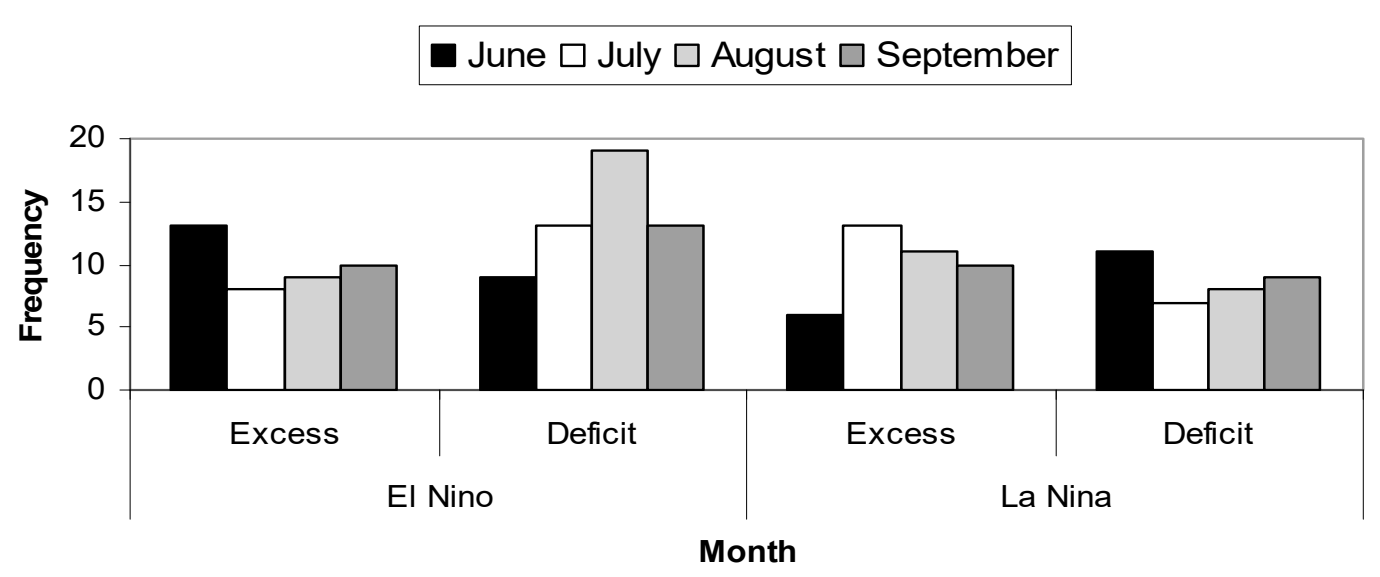

Figure 7. Frequency of excess and deficit of rainfall during monsoon under El Niño and La Niña.

Funding: This work is supported by Special Grant from China Postdoctoral Science Foundation (No.2020T130311).

Institutional Review Board Statement: Not applicable.

Informed Consent Statement: Not applicable.

Data Availability Statement: Data will be available upon request.

Conflicts of Interest: The author declares no conflict of interest.

\section{References}

1. Ali, A. Vulnerability of Bangladesh to climate change and sea level rise through tropical cyclones and storm surges. Water Air Soil Pollut. 1996, 92, 171-179.

2. Ali, A. Climate change impacts and adaptation assessment in Bangladesh. Clim. Res. 1999, 12, 109-116. [CrossRef]

3. Ali, A. Cyclone; Bangla Academy: Dhaka, Bangladesh, 1999; p. 147.

4. Zebiak, S.E.; Cane, M.A.A. Model El Niño-Southern Oscillation. Mon. Weather Rev. 1987, 115, 2262-2278. [CrossRef]

5. Wallace, J.M. El Niño and Climate Prediction; Washington University Press: Washington, DC, USA, $1994 ;$ Volume 3, p. 142.

6. Wang, H.J.; Zhang, R.H.; Cole, J.; Chavez, F. El Niño and the related phenomenon Southern Oscillation (ENSO), The largest signal in interannual climatic variation. Proc. Natl. Acad. Sci. USA 1999, 96, 11071-11072. [CrossRef]

7. Pastor, R. El Niño Climate Pattern Forms in Pacific Ocean; USA Today: McLean, VA, USA, 2006.

8. Miah, M.M. Flood in Bangladesh; Academic Publishers: Dhaka, Bangladesh, 1988.

9. Islam, A.R.M.T.; Talukdar, S.; Mahato, S.; Kundu, S.; Eibek, K.U.; Pham, Q.B.; Kuruki, A.; Linh, N.T.T. Flood susceptibility modelling using advanced ensemble machine learning models. Geosci. Front. 2021, 12, 101075. [CrossRef]

10. Brammer, H. Floods in Bangladesh: Geographical background to the 1987 and 1988 floods. Geogr. J. 1990, 156, 12-22. [CrossRef]

11. Mohapatra, M.; Bandyopadhyay, B.K.; Tyagi, A. Best track parameters of tropical cyclones over the North Indian Ocean: A review. Nat. Hazards 2012, 63, 1285-1317. [CrossRef]

12. Singh, O.P.; Ali-Khan, T.M.; Rahman, M.S. Changes in the frequency of tropical cyclones over the North Indian Ocean. Meteorol. Atmos. Phys. 2000, 75, 11. [CrossRef]

13. Wahiduzzaman, M.; Yeasmin, A. Statistical forecasting of tropical cyclone landfall activities over the North Indian Ocean rim. Atmos. Res. 2019, 227, 89-100. [CrossRef]

14. Wahiduzzaman, M.; Oliver, E.C.J.; Wotherspoon, S.J.; Holbrook, N.J. A climatological model of North Indian Ocean tropical cyclone genesis, tracks and landfall. Clim. Dyn. 2017, 49, 2585-2603. [CrossRef]

15. Balaguru, K.; Taraphdar, S.; Leung, L.R.; Foltz, G.R. Increase in the intensity of postmonsoon Bay of Bengal tropical cyclones. Geophys. Res. Lett. 2014, 41, 3594-3601. [CrossRef]

16. Sahoo, B.; Bhaskaran, P.K. Assessment on historical cyclone tracks in the Bay of Bengal, east coast of India. Int. J. Clim. 2016, 36, 95-109. [CrossRef]

17. Wahiduzzaman, M.; Oliver, E.C.J.; Klotzbach, P.J.; Wotherspoon, S.J.; Holbrook, N.J. A statistical seasonal forecast model of North Indian Ocean tropical cyclones using the Quasi-biennial Oscillation. Int. J. Clim. 2019, 39, 934-952. [CrossRef]

18. Wahiduzzaman, M.; Yeasmin, A. A kernel density estimation approach of North Indian Ocean tropical cyclone formation and the association with convective available potential energy and equivalent potential temperature. Meteorol. Atmos. Phys. 2020, 132, 603-612. [CrossRef]

19. Girishkumar, M.S.; Ravichandran, M. The influences of ENSO on tropical cyclone activity in the Bay of Bengal during OctoberDecember. J. Geophys. Res. Ocean. 2012, 117. [CrossRef] 
20. Wahiduzzaman, M.; Oliver, E.; Wotherspoon, S.; Luo, J.J. Statistical forecasting of tropical cyclones over the North Indian Ocean and the role of El Niño-Southern Oscillation. Clim. Dyn. 2020, 54, 1571-1589. [CrossRef]

21. Girishkumar, M.S.; Suprit, K.; Vishnu, S.; Prakash, V.P.T.; Ravichandran, M. The role of ENSO and MJO on rapid intensification of tropical cyclones in the Bay of Bengal during October-December. Theor. Appl. Climatol. 2015, 120, 797-810. [CrossRef]

22. Felton, C.S.; Subrahmanyam, B.; Murty, V.S.N. ENSO-modulated cyclogenesis over the Bay of Bengal. J. Clim. 2013, 26, 9806-9818. [CrossRef]

23. Choudhury, A.M. Bangladesh Floods, Cyclones \& the ENSO. In Proceedings of the International Monsoon Conference, Trieste, Italy, 9-13 May 1994; WCRP-84 and WMO/TD-No. 619. WMO: Geneva, Italy, 1994.

24. Singh, O.P.; Khan, T.M.A.; Rahman, S. Probable reasons for enhanced cyclogenesis in the Bay of Bengal during July-August of ENSO years. Glob. Planet. Chang. 2001, 29, 135-147. [CrossRef]

25. Mandal, G.S. Low Frequency Oscillation and Seasonal Variability of Tropical Cyclones; Topics Chairman and Rapporteur's Report of the Second WMO Workshop on Tropical Cyclones (IWTC-II); WMO/TD No. 319; World Meteorological Organization: Geneva, Switzerland, 1989.

26. Mandal, G.S. Low Frequency Oscillation and Seasonal Variability of Tropical Cyclones of North Indian Ocean. Ph.D. Thesis, Jadavpur University, Kolkata, India, 1990; pp. 406-444.

27. Girishkumar, M.S.; Thanga Prakash, V.P.; Ravichandran, M. Influence of Pacific Decadal Oscillation on the relationship between ENSO and tropical cyclone activity in the Bay of Bengal during October-December. Clim. Dyn. 2014, 44, 3469-3479. [CrossRef]

28. Wahiduzzaman, M.; Yeasmin, A.; Luo, J.J. Seasonal movement prediction of tropical cyclone over the North Indian Ocean by using atmospheric climate variables. Atmos. Res. 2020, 245, 105089. [CrossRef]

29. Wahiduzzaman, M.; Yeasmin, A.; Luo, J.J.; Quadir, D.A.; Amstel, A.V.; Cheung, K.W.; Yuan, C. Markov Chain Monte Carlo simulation and regression approach guided by El Niño-Southern Oscillation to model the tropical cyclone occurrence over the Bay of Bengal. Clim. Dyn. 2021, 5, 1-12.

30. Wahiduzzaman, M.; Luo, J.J. A statistical analysis on the contribution of El Niño-Southern Oscillation to the rainfall and temperature over Bangladesh. Meteorol. Appl. Phys. 2021, 133, 55-68. [CrossRef] 